\title{
Relationships among cyanobacteria, zooplankton and fish in sub-bloom conditions in the Sulejow Reservoir
}

\author{
Zbigniew KACZKOWSKI, ${ }^{1 *}$ Adrianna WOJTAL-FRANKIEWICZ, ${ }^{1}$ Ilona GĄGAŁA, ${ }^{2}$ Joanna MANKIEWICZ-BOCZEK, ${ }^{2}$ \\ Aleksandra JASKULSKA, ${ }^{1,2}$ Piotr FRANKIEWICZ, ${ }^{1}$ Katarzyna IZYDORCZYK, ${ }^{2}$ Tomasz JURCZAK, ${ }^{1}$ \\ Małgorzata GODLEWSKA ${ }^{2}$
}

${ }^{1}$ Department of Applied Ecology, University of Lodz, Banacha 12/16 Str., 90-237 Lodz; ${ }^{2}$ European Regional Centre for Ecohydrology, Polish Academy of Sciences, Tylna 3 Str., 90-364 Lodz, Poland

*Corresponding author: kaczko@biol.uni.lodz.pl

\begin{abstract}
The occurrence of cyanobacteria is particularly characteristic of shallow eutrophic waters, and they often form massive 'blooms' that can affect aquatic invertebrates and fish. However, even a low abundance of cyanobacteria can be hazardous to aquatic organisms, due to the production of toxic metabolites. The aim of this study was to investigate the relationship between cyanobacteria and their toxicity (biological activity) towards zooplankton and fish communities, when only low concentrations of cyanobacterial chlorophyll $a$ (less than $20 \mu \mathrm{g} \mathrm{L}^{-1}$ ) are detected, i.e. in sub-bloom conditions. Measurements were performed in Sulejow Reservoir (Central Poland), a shallow, lowland, eutrophic reservoir, in which cyanobacterial blooms occur regularly. Fish were assessed using echo-sounding (distribution) and by gillnetting (species composition). Simultaneously, zooplankton, cyanobacteria and physicochemical characteristics were studied at 14 stations situated along hydroacoustic transects. Parameters that characterized the cyanobacteria (cyanobacterial chlorophyll $a$ concentration, the number of $16 \mathrm{~S}$ rRNA and the mcyA gene copies and microcystin (MC) concentration) were consistently correlated (based on a principal component analysis), and the highest values were found in the downstream region of the study area. This 'cyano-complex' was also positively correlated with oxygen concentration, $\mathrm{pH}$ and phosphate levels, but was negatively correlated with temperature and the concentrations of nitrates and nitrites. In Sulejow Reservoir in 2013 the biomass of large zooplankton filter feeders decreased along with increasing MC concentration and fish densities, while small filter feeders did not present such relationships with regards to fish densities. Fish abundance tended to decrease at stations with a lower abundance of cyanobacteria and with growing toxic genotype copies and MC concentration.
\end{abstract}

Key words: Fish spatial distribution; microcystins; toxic bloom; eutrophic reservoir; filter feeders; biotic interactions.

Received: May 2016. Accepted: January 2017.

\section{INTRODUCTION}

Since the 1960s when cyanobacteria blooms were recognized as one symptom of eutrophication, studies of cyanobacteria have been 'bloom oriented' (Bishop et al., 1959). Further research has shown that cyanobacteria are hazardous to both aquatic life (Chen et al., 2006; Xie et al., 2007) and human health (Chen et al., 2009). Toxigenic cyanobacteria produce potent bioactive (toxic) secondary metabolites such as microcystins (MCs), which are hepatotoxic to aquatic animals (Martins and Vasconcelos, 2009). The toxicity of MCs results from the inhibition of phosphatase activity and the consequent excessive phosphorylation of proteins and damage to the cytoskeleton. MCs also induce oxidative stress in aquatic animals by increasing the production of reactive oxygen species, which cause cell membrane damage via lipid peroxidation, the loss of glutathione from the cells, and DNA damage (Wiegand and Pflugmacher, 2005; Amado and Monserrat, 2010). The negative impact of MCs in animals is also due to the accumulation of toxins in their tissues (Xie et al., 2004).

Some limnological studies have specifically focused on the effect of cyanobacteria during bloom events on the life histories of zooplankton, because herbivorous zooplankton are the major phytoplankton consumers and form an important link between primary producers and higher trophic levels, e.g. fish. Cyanobacteria particularly affect herbivorous zooplankton. Their non-selective filtering process and the broad spectrum of particle sizes consumed by large zooplankton filter feeders, such as Daphnia (Lampert, 1987), make them the most vulnerable to cyanotoxin poisoning (Rohrlack et al., 1999). However, the impact of cyanobacteria on aquatic biota is not restricted to their toxicity. The consumption of many species of cyanobacteria by zooplankton is difficult or impossible due to their morphology. The cell shape and size of the colonies and the filaments formed by cyanobacteria disturb mechanical aspects of the filtering process, particularly for the large-bodied grazers of the genus Daphnia 
(DeMott et al., 2001). The absence of sterols and polyunsaturated fatty acids (Martin-Creuzburg et al., 2008) and the production of protease inhibitors (Schwarzenberger et $a l ., 2010)$ makes cyanobacteria a poor-quality food for zooplankton. Furthermore, the gelatinous or mucilaginous sheath produced by certain cyanobacteria species, e.g. Microcystis sp., protects the cells from digestion, which means that cyanobacteria can pass through the gut of Daphnia intact and alive and can collect nutrients from Daphnia during passage through their gut (Porter, 1976). As a result, cyanobacteria can reduce herbivorous zooplankton fitness due to malnutrition (Paerl and Otten, 2013). Consequently, cyanobacteria can cause a decrease in the population growth, fecundity and survival of herbivorous zooplankton (Fulton and Paerl, 1987), as well as change their behavior and phenotypic adaptations (Berthon and Brousse, 1995; Ghadouani and Pinel-Alloul, 2002). A few studies have indicated asynchrony in the spatial distribution of zooplankton and cyanobacteria within lakes and the formation of 'refuge sites' that allow large grazers to persist during blooms (Roy, 2008; Reichwaldt et al., 2013). However, there is an evident gap in our knowledge regarding the possibility that such mechanisms also develop during sub-bloom periods, if low concentrations of cyanobacteria are present.

The relationship between fish and the presence of cyanobacteria are a less recognized issue than the cyanobacteria - zooplankton interaction, but studies on this topic are still usually 'bloom-oriented'. Fish mortality is the most spectacular evidence of the harmful impact of cyanobacteria (Ochumba, 1990; Sevrin-Reyssac and Pletikosic, 1990; Jewel et al., 2003). The reasons for fish mortality are frequently indirect and are linked with the sudden hypoxic conditions that can appear with the senescence of a cyanobacterial bloom. However, in the case of the trout mortality observed at Loch Leven, healthy levels of oxygen were maintained in the lake, but severe liver damage after the lysis of a toxic Dolichospermum (Anabaena) flos-aquae (Brébisson ex Bornet \& Flahault) bloom was observed, a reaction similar to that of fish administered MC extracts (Rodger et al., 1994). The negative responses of fish exposed to cyanotoxins, especially MCs, are not limited to hepatotoxicity, but also include nephrotoxicity, immunotoxicity or changes in biochemical and hematological parameters (Rodger et al., 1994; Kotak et al., 1996; Malbrouck and Kestemont, 2006; Chen et al., 2009; Kopp et al., 2009; Qiu et al., 2009; Sieroslawska et al., 2012). Developmental processes and behaviors can also be disturbed (Oberemm et al., 1999; Baganz et al., 2004; Wang et al., 2005). An additional problem is the risk of MC bioaccumulation that can occur in fish over their relatively long life span and the effect this can have on public health. However, most bioaccumulation studies refer to the laboratory conditions in which fish were exposed to high concentrations of purified MCs (Malbrouck et al., 2003; Soares et al., 2004; Xie et al., 2004; Li et al., 2005; Mohamed and Hussein, 2006). These results are not readily transferable to more complex natural systems, and only a few studies have addressed the accumulation of cyanobacteria toxins in uncontrolled conditions (Magalhàes et al., 2001; Mohamed et al., 2003; Cazenave et al., 2005; Xie et al., 2005; Chen et al., 2006; Xie et al., 2007; Papadimitriou et al., 2012; Trinchet et $a l ., 2013)$. The relationship between the spatial distribution of fish relative to bloom occurrence is an even less well known issue (Wojtalik et al., 2006; Ernst, 2008; Sotton et al., 2011). A possible reason for the scarcity of spatial 'bloom-fish' studies is the fact that fish dispersal is a highly dynamic phenomenon, induced by a complex interaction of environmental factors that influence fish behavior, e.g. temperature, oxygen concentrations (Guillard et al., 2006; Mehner et al., 2010), the patchiness of food resources, and the presence of predators (Gliwicz and Jachner, 1992; Frankiewicz et al., 1996, 1997).

The behavioral changes of the fish in response to the presence of cyanobacteria are probably complex and may vary depending on the fish and the cyanobacteria species involved, the level of cyanobacteria toxicity, and the environmental parameters. Therefore, in our study, we investigated the relationship between biomass, the abundance of fish and zooplankton and the spatial distribution and biological activity (MC toxicity) of the cyanobacteria, considering the influence of environmental factors, such as temperature, oxygenation, $\mathrm{pH}$, and nutrient concentrations. This study used simultaneous measurement of fish, zooplankton, and physico-chemical feedback parameters in the presence of a low concentration of chlorophyll $a$, however with genotypes of cyanobacteria with a high toxigenic potential in a shallow polymictic reservoir. We hypothesized that: i) even in a sub-bloom period, the values of cyanobacteria densities (measured as cyanobacterial chlorophyll $a$ concentration or the number of 16sRNA gene copies) will be negatively correlated with the biomass or the densities of large zooplankton and fish; ii) large zooplankton will be negatively correlated with fish distribution; and iii) MC concentration and their biological activity will negatively influence the biomass or densities of zooplankton and fish.

\section{METHODS}

\section{Sulejow Reservoir}

The study site, the Sulejow Reservoir, is located in the lowlands of the central region of Poland, $138.9 \mathrm{~km}$ from the mouth of the Pilica River $\left(51^{\circ} 22^{\prime}-51^{\circ} 28^{\prime} \mathrm{N}\right.$ and $19^{\circ}$ $51^{\prime}-20^{\circ} 01^{\prime}$ E, Fig. 1). The reservoir was built in 1973 and belongs to the Vistula River catchment; its maximum length 
is $15.5 \mathrm{~km}$, and its maximum width is $2.1 \mathrm{~km}$. The surface covers $1980 \mathrm{ha}$, with a mean depth of $3.3 \mathrm{~m}\left(75 \times 10^{6} \mathrm{~m}^{3}\right)$. During the study period, the maximal depths changed from $7 \mathrm{~m}$ (e.g., stations no. $1,3,7)$ near the dam to less than $6 \mathrm{~m}$ in the upstream section of the study area (e.g., stations no. $13,14)$. The reservoir sub-catchment area is primarily covered with agricultural land $(50 \%$ arable land, $13 \%$ meadows and pastures, $1 \%$ orchards) and forests $(31 \%)$. The shoreline length is approximately $54 \mathrm{~km}$. The reservoir is a polymictic and eutrophic ecosystem (Wagner et al., 2009). Within the lake basin, three distinct areas are recognizable: the upper 'riverine', middle 'transitional' and lower 'lacustrine' portions, which are distinguished based on their hydro-chemical and biological parameter dynamics (Izydorczyk et al., 2009). Our measurements were concentrated in the lacustrine, the deepest portion of the reservoir which for the purpose of analysis was divided into upstream and downstream parts. Water transparency varied from 0.95 $1.5 \mathrm{~m}$ in July to $0.85-1.45 \mathrm{~m}$ in September. This area is characterized by stable hydrological conditions, with retention times of up to 60 days, and a high supply of nutrients from the catchment area, which favors cyanobacterial growth, mainly Microcystis aeruginosa Kütz. and Aphanizomenon flos-aquae (L.) (Izydorczyk et al., 2008). The dominant species of bloom-forming cyanobacteria is $M$. aeruginosa, which produces microcystin-LR (MC-LR), microcystin-YR (MC-YR) and MC-RR (Jurczak et al., 2005; Gągała et al., 2014). In 2013 the dominant genera of the phytoplankton identified during the spring (May-June) in

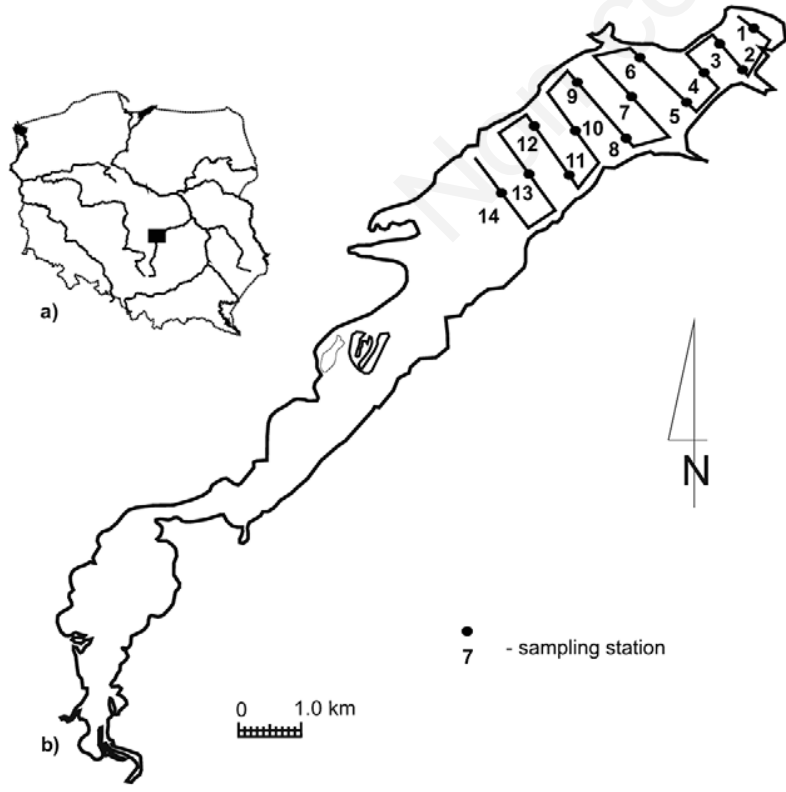

Fig. 1. Location of Sulejow Reservoir on the River Pilica, Poland (a) with the hydroacoustic transect arrangement plan in the reservoir and sampling station distribution (b). the Sulejow Reservoir were as follows: Euglena sp. (Euglenophyta), Fragilaria sp., Navicula sp. (Bacillariophyceae) and Closterium sp. (Chlorophyta). In the summer (July, August), besides cyanobacteria, we identified Asterionella formosa (Hassall) (Bacillariophyceae), Scenedesmus sp. (Chlorophyta) and all of the genera that were present during the spring. In September and October Euglena sp., Fragilaria sp., Navicula sp., Asterionella formosa, Melosira varians (C. Agardh), Nitzschia sp. (Bacillariophyceae) and Crucigenia rectangularis ((Nägeli) Gay) (Chlorophyta) were still detected in the Sulejow Reservoir.

The reservoir is inhabited by a stable and cypriniddominated fish assemblage, with a biomass of approximately $114 \mathrm{~kg} \mathrm{ha}^{-1}$, including common bream (Abramis brama L.), white bream (Blicca bjöerkna L.), and roach (Rutilus rutilus L.) among the cyprinids and pikeperch (Stizostedion lucioperca L.) among the piscivores. Other fish species regularly observed in gillnet catches include Eurasian perch (Perca fluviatilis L.), bleak (Alburnus alburnus L.), ruffe (Gymnocephalus cernua L.), asp (Aspius aspius L.) and pike (Esox lucius L.) (Frankiewicz et al., 1999; Frankiewicz and Świerzowski, 2004).

\section{Sampling strategy}

Night-time measurements were chosen to decrease the impact of behavioral factors such as fish using vegetation cover during the day for predator avoidance and dispersal to the open water after dusk to feed under the cover of night (Gliwicz and Jachner, 1992; Guillard et al., 2006; Mehner et al., 2010).

Water sampling and direct measurements (temperature, oxygen concentration, $\mathrm{pH}$ and conductivity) in the reservoir were performed at 14 stations located along 10 parallel transects established for hydroacoustic surveys (Fig. 1). Data collection was performed during the sub-bloom summer period on four nights: 16 and 18 July and 23 and 25 September 2013. A YSI ProODO Digital Professional Series (Ohio, USA) meter with an optical oxygen sensor and a WTW Multi 3420 (Weilheim, Germany) meter were used for in-situ measurements of the basic physico-chemical parameters (temperature, oxygen concentration, $\mathrm{pH}$ ). Temperature and oxygen concentration were measured once per meter, from the surface to the bottom. The results are presented as the mean values calculated separately for each sampling station. $\mathrm{pH}$ was measured once at every sampling station in unified water samples. The water samples used for laboratory analyzes were chilled for transport in an isothermic Styrofoam box with ice.

\section{Laboratory analyzes}

\section{Abiotic factors}

Dissolved forms of nitrogen and phosphorus were analyzed in a laboratory using an ion chromatography sys- 
tem (Dionex ICS-1000, Waltham, MA, USA), which facilitated the qualitative and quantitative analysis of anions $\left(\mathrm{NO}_{2}^{-}, \mathrm{NO}_{3}^{-}, \mathrm{PO}_{4}{ }^{3-}\right)$ and cations $\left(\mathrm{NH}^{4+}\right)$ in filtered water samples, as described by Gągała et al. (2012).

\section{Biotic factors}

\section{Phytoplankton analyzes}

The concentration of chlorophyll $a\left(\mu \mathrm{g} \mathrm{L}^{-1}\right)$ was measured immediately after sampling in a 1-L integrated water sample using a bbe Algae Online Analyzer (AOA, Version 1.5 E1, bbe-Moldaenke company Kiel, Germany). This analyzer takes measurements based on the determination of the fluorescence spectrum and kinetics of the algae. By analyzing the interaction of chlorophyll $a$ (Chloa) with other pigments, the AOA discriminates among four main groups of algae (green algae, cyanobacteria, cryptophytes and diatoms). In this study, 'Chloa' represents the sum of the values for green algae, cyanobacteria, cryptophytes and diatoms and this was used as the indicator of total phytoplankton availability, while 'cyanobacterial chlorophyll $a$ ' (Cya) was used as the indicator of cyanobacterial abundance. The AOA analysis was earlier calibrated for the Sulejow Reservoir and this has been described by Izydorczyk et al. (2009). Random samples were additionally subjected to microscopic analysis, to validate AOA calibration for the need of the current study. Phytoplankton estimations were performed according to Izydorczyk et al. (2009). Samples for the determination of phytoplankton biovolume were preserved in Lugol's solution and sedimented in the laboratory. Phytoplankton were counted in concentrated samples, using a Fusch-Rosenthal counting chamber and a Nikon Optiphot-2, 102 (400x magnification). At least 400 cells or filaments were counted to reduce the error to less than $10 \%(\mathrm{p}=0.05)$. Phytoplankton biovolume $\left(\mathrm{mm}^{3} \mathrm{~L}^{-1}\right)$ was determined based on a volumetric analysis of cells using geometric approximation.

\section{Genetic analyzes of cyanobacteria}

The samples of water for DNA assays (always $100 \mathrm{~mL}$ of water was collected) were prepared according to Mankiewicz-Boczek et al. (2006). Filters with cyanobacterial material (pore diameter $0.45 \mu \mathrm{m}$, Millipore, USA) were put into the lysis buffer containing $40 \mathrm{mM}$ EDTA, 400 $\mathrm{mM} \mathrm{NaCl}, 0.75 \mathrm{M}$ sucrose, and $50 \mathrm{mM}$ TRIS-HCl (pH 8.3) and frozen as soon as possible. Genetic material was extracted from the filters according to Giovannoni et al. (1990), with some modifications, which improved the extracted DNA quality and quantity, as described by Mankiewicz-Boczek et al. (2006). For the centrifugation, a speed of 13,000 rpm was used. For the enzymatic lysis step, a final concentration of proteinase K (Fermentas, Lithuania) of $275 \mu \mathrm{g} \mathrm{mL}-1$ was used. During the phenol/chloroform step, a volume of chloroform/isoamyl alcohol (24:1) equal to the volume of supernatant was used.

Extracted DNA was used as the template for quantitative (qRT-PCR, quantitative real-time PCR) determination of: the 16S rRNA ( $250 \mathrm{bp})$ gene fragment specific for the genus Microcystis; and the mcyA (395 bp) gene fragment specific for toxic Microcystis genotypes. The analysis of qRT-PCR was made with the use of Maxima ${ }^{\mathrm{TM}}$ SYBR Green/ROX qPCR Master Mix (MBI Fermentas) and a real-time PCR system (7900HT, Applied Biosystems).

The qRT-PCR analyzes for 16S rRNA and $m c y$ A were prepared according to Gągała et al. (2014). Each reaction was performed in a final volume of $25 \mu \mathrm{L}$. The ingredients, including $1 \times$ Maxima SYBR green qPCR master mix, $1 \mu \mathrm{L}$ of template DNA, and $0.3 \mu \mathrm{M}$ of each primer, were mixed on ice. A three-step cycling protocol was used after an initial denaturation step at $95^{\circ} \mathrm{C}$ for $5 \mathrm{~min}$ and this was followed by 45 cycles of DNA denaturation at $95^{\circ} \mathrm{C}$ for $15 \mathrm{~s}$; then, primer annealing at $56^{\circ} \mathrm{C}(\mathrm{g} 91), 51^{\circ} \mathrm{C}(16 \mathrm{~S}$ rRNA) and $55^{\circ} \mathrm{C}(m c y A)$ for $30 \mathrm{~s}$ and strand extension step at $72^{\circ} \mathrm{C}$ for $1 \mathrm{~min}$. In order to prepare the calibration standards for $16 \mathrm{~S} \mathrm{rRNA} / m c y \mathrm{~A}$, the genomic DNA of $M$. aeruginosa strain PCC7820, which had been provided by Åbo University, was used as a template for PCR amplification of reference sequences.

\section{Chromatographic analyzes of microcystins}

For high-performance liquid chromatography (HPLC) analyzes, 1-L water samples containing cyanobacterial material were filtered through $\mathrm{GF} / \mathrm{C}$ filters (Whatman, Kent, UK; GF/C, $1.20 \mu \mathrm{m}$ ) immediately after sampling. The preparation of cyanobacterial material and the determination of MCs concentration via HPLC-DAD were performed according to Jurczak et al. (2005). Dissolved MC samples were concentrated in Baker (Deventer, The Netherlands) C18 solid phase extraction (SPE) cartridges (sorbent mass: $1000 \mathrm{mg}$ ). MCs were eluted from the $\mathrm{C} 18$ cartridges using $3 \mathrm{~cm}^{3}$ of $90 \%$ aqueous methanol containing $0.1 \%$ trifluoroacetic acid (TFA). The eluates were evaporated to dryness, and the samples were redissolved in $1 \mathrm{~mL}$ of $75 \%$ aqueous methanol prior to HPLC analysis. The average recovery for the SPE (from triplicate samples) was $88 \%$ for MC-YR, $98 \%$ for MC-LR and $99 \%$ for MC-RR. Intracellular MC compounds were extracted in $75 \%$ aqueous methanol. The samples were sonicated for $30 \mathrm{~s}$ in a Misonix (Farmingdale, NY, USA) ultrasonicator equipped with an ultrasonic probe $(100 \mathrm{~W}$, diameter $19 \mathrm{~mm}$ with 'spike') and an XL liquid processor. The extracts were centrifuged twice at $11000 \mathrm{rpm}$ for $10 \mathrm{~min}$ at $4^{\circ} \mathrm{C}$ using an Eppendorf 5804 centrifuge (Hamburg, Germany). The supernatants were collected and evaporated using an SC110A Speedvac ${ }^{\circledR}$ Plus, ThermoSavant (Holbrook, NY, USA). Before performing the HPLC analysis, the samples were redissolved in $1 \mathrm{~mL}$ of $75 \%$ aqueous methanol and filtered through a Gelman GHP Acrodisc 
13-mm syringe filter with a $0.45-\mu \mathrm{m}$ GHP membrane and a minispike outlet (East Hills, NY, USA). The MCs were identified as intra- and extracellular against the MC standards for MC-RR, MC-YR and MC-LR. The limit of MC detection was $0.01 \mu \mathrm{g} \mathrm{L}^{-1}$.

\section{Protein phosphatase inhibition assay}

The protein phosphatase inhibition assay was performed with a MicroCystest screening immuno-bioassay (ZEU-Inmunotec, Zaragoza, Spain) to confirm the biological activity of MCs, i.e. their toxicity. MicroCystest is based on the inhibition of PP2A (rabbit skeletal muscle) activity by MCs, the mechanism of action used by these toxins in hepatocytes (PP2A is able to hydrolyze a specific substrate that can be detected at $405 \mathrm{~nm}$ ). Samples containing MCs inhibit the enzyme activity proportionally to the amount of toxin contained in a sample. The test is able to detect all toxic MCs present in a sample. Assessments of the actual biological activity of MCs were performed according to the manufacturer's instructions (ZeuLab, Zaragoza, Spain). The assay range of the method is between 0.25 and $2.5 \mu \mathrm{g} \mathrm{L}^{-1}$. The concentration of MCs in the sample was expressed in microcystin-LR equivalents.

\section{Zooplankton assessment}

Zooplankton were sampled from each meter of the entire water column at the fourteen sampling points using a 5-L Bernatowicz sampler. The samples were filtered with a $56-\mu \mathrm{m}$ mesh-size plankton net. The collected zooplankton were preserved in $4 \%$ Lugol's solution. The samples were concentrated to $1 \mathrm{~mL}$, identified, and counted under a Nikon microscope using a Sedgewick Rafter counting chamber. Morphological analyzes of the collected individuals were performed according to Amoros (1984) and Benzie (2005). The biomass for a particular zooplankton genus (wet weight) was estimated based on species-specific length/weight regression curves (Bottrell et al., 1976).

\section{Hydroacoustic measurements and fish gillnetting}

The fish community was studied using two sampling methods that supplemented each other. Hydroacoustics provided high-resolution data on the spatiotemporal distribution of fish and absolute fish abundance, and gillnetting was used to assess species composition and size distributions. The hydroacoustic measurements were conducted from a boat sailing at a constant speed of $1.5 \mathrm{~m} \mathrm{~s}^{-}$ ${ }^{1}$ along 10 predetermined transects (Fig. 1). The survey was started at least one hour after sunset, when fish dispersed in the open water, and was completed at least one hour before sunrise to avoid the effects of diurnal behavior of the fish (Drastík et al., 2009).

A SIMRAD EK60 (Horten, Norway) split-beam echosounder operating at $200 \mathrm{kHz}$ was used with a transducer of 7 degrees (at $-3 \mathrm{~dB}$ ), beaming horizontally. The recorded range was $50 \mathrm{~m}$, which corresponds to the acoustic sampling of an approximate depth of $6 \mathrm{~m}$, which reached the bottom of Sulejow Reservoir (Kubecka, 1996). The pulse duration was $0.128 \mathrm{~ms}$, and the repetition rate was 5 times per second. The echo-sounder was calibrated vertically in the deepest portion of the lake at the beginning of the study following standard calibration procedure (Foote et al., 1987). The data were stored in a computer and later processed using Sonar 5 Pro software (Balk and Lindem, 2011). The volumetric numerical estimates of fish density were performed using the echo integration method (Sv/TS scaling) (Balk and Lindem, 2011). Single-echo detections (SEDs) after deconvolution (Kubecka, 1996) were used as the source of the target strength (TS) distributions in units of $\mathrm{dB}$. The thresholds were fixed at $-45 \mathrm{~dB}$ for individual targets $(40 \log \mathrm{R})$ and $-51 \mathrm{~dB}$ for the amplitude echogram. To recalculate fish numerical density into fish biomass, the relationship between the acoustical size TS in $\mathrm{dB}$ and fish length in centimeters is required. Frouzova's regression for pooled common European species was used (Frouzova, 2005), as this was shown to give the best biomass estimate in another Polish lowland reservoir (Godlewska et al., 2012). With respect to the locations of the 14 stations for each sampling point, each transect length was divided into three equal sections (so-called integration intervals), and the fish abundance estimated for each section was assumed to correspond to a given station. With horizontal beaming, only volume density estimates are possible. The areal fish density (more commonly used by fisherman) is presented as the multiplication of the volume density by the average lake depth, i.e. $3 \mathrm{~m}$.

Gillnetting was performed at two sites perpendicular to the shoreline on 17 July and 24 September. One set of nets was located in the area with the lower Cya concentration, and one set was located in the area with the Cya, as measured the previous night. Due to the abundance of large fish (bream, roach) that are difficult to catch with standardized gillnets (European Committee for Standardization, 2005), specially designed multi-mesh gillnets that were $77 \mathrm{~m}$ long and $3.0 \mathrm{~m}$ deep were used. The gillnets were composed of 11 different mesh-sizes ranging from $11 \mathrm{~mm}$ to $80 \mathrm{~mm}$ from knot to knot (mesh panel size and order: $11,24,50,60,30,70,35,80,40,20$, and $16 \mathrm{~mm}$ ). Sampling was performed at the same time as the hydroacoustic survey.

Fish sampling via gillnetting is part of the standard fishery management procedures in the reservoir (yield limit $0.5 \mathrm{t} \mathrm{yr}^{-1}$ ) and fishing (number of gillnets or biomass of the yield) was not increased because of this study. The capture of wild animals for the purpose of taking biometric measurements and determining their taxonomic classification is exempt from the requirements of Ethics Committee ap- 
proval in Poland (Art. 1 pt. 2.4 of the Act on the protection of animals used for scientific or educational purposes of 15 January 2015, which is the Polish implementation of Directive 2010/63/EU of the European Parliament and of the Council of Europe from 22 September 2010 on the protection of animals used for scientific purposes (O.J.EUL276 of 20.10.2010, p.33)). Sampling via gillnetting was performed in accordance with the Inland Fishery Act with the permission of the Lodz Voivodeship Marshal (No. RŚS.7143.1.2013.PP). After sampling, data on the catch within each gillnet were recorded, including the number of individuals and the total length and weight for each specimen. Fish were owned by the fishery manager and were sold for consumption after measurements were taken. None of the activities in this study involved endangered or protected species.

\section{Statistical analysis}

A principal component analysis (PCA) was applied to reduce the number of environmental variables, including physico-chemical parameters and cyanobacteria-connected factors. The PCA was carried out using $\log (\mathrm{x}+1)$ transformed data. The values generated for each principal component were then regressed against the fish and large zooplankton biomasses and densities. Pearson correlation coefficients were calculated to reveal the relationships between biological parameters. Additionally, to test for the effect of the season (July, September) and reservoir region (upstream, downstream) on the PC values, a two-way ANOVA was performed with season and reservoir region as the categorical factors and $\mathrm{PC}$ value as the dependent factor. The t-test was used to determine whether there were significant differences between the means of the two groups of compared parameters. All calculations were performed using Statistica 10 (Statsoft, Inc., www.statsoft.com).

\section{RESULTS}

\section{Abiotic factors}

The average temperature, oxygen and $\mathrm{pH}$ values were $21^{\circ} \mathrm{C}, 7.5 \mathrm{mg} \mathrm{L}^{-1}$ and 8.0 in July and $15^{\circ} \mathrm{C}, 9.3 \mathrm{mg} \mathrm{L}^{-1}$ and 8.5 in September, respectively (Tab. 1). Nitrate concentrations of approximately $1-1.7 \mathrm{mg} \mathrm{L}^{-1}$ were found in all samples collected on 16 and 18 July. However, in September, all samples had concentrations equal to or lower than $1 \mathrm{mg} \mathrm{L}^{-1}$. The nitrite concentrations were rather low, in the range of 0 to $0.06 \mathrm{mg} \mathrm{L}^{-1}$. Similar values were found for ammonium ions in July. In September, in contrast to nitrate and nitrite concentrations, the concentration

Tab. 1. Characteristics of the abiotic and biotic parameters at the Sulejow Reservoir, Central Poland (average values for all sampling stations).

\begin{tabular}{|c|c|c|c|c|c|}
\hline \multirow[t]{2}{*}{ Parameter } & & \multicolumn{4}{|c|}{ Sampling data } \\
\hline & & 2013-07-16 & 2013-07-18 & 2013-09-23 & 2013-09-25 \\
\hline \multicolumn{6}{|c|}{ Abiotic factors } \\
\hline Temperature & $\left({ }^{\circ} \mathrm{C}\right)$ & $20.6 \pm 0.2$ & $21.5 \pm 0.4$ & $15.2 \pm 0.2$ & $14.7 \pm 0.1$ \\
\hline Oxygen concentration & $\left(\mathrm{mg} \mathrm{L}^{-1}\right)$ & $7.3 \pm 1.1$ & $7.7 \pm 1.3$ & $9.2 \pm 0.3$ & $9.4 \pm 0.7$ \\
\hline $\mathrm{pH}$ & & $7.9 \pm 0.1$ & $8.2 \pm 0.2$ & $8.5 \pm 0.1$ & $8.5 \pm 0.1$ \\
\hline Nitrates & $\left(\mathrm{mg} \mathrm{L}^{-1}\right)$ & $1.24 \pm 0.20$ & $1.29 \pm 0.25$ & $0.45 \pm 0.31$ & $0.61 \pm 0.19$ \\
\hline Nitrites & $\left(\mathrm{mg} \mathrm{L}^{-1}\right)$ & $0.02 \pm 0.02$ & $0.03 \pm 0.01$ & $0.00 \pm 0.00$ & $0.01 \pm 0.01$ \\
\hline Ammonium & $\left(\mathrm{mg} \mathrm{L}^{-1}\right)$ & $0.02 \pm 0.01$ & $0.02 \pm 0.01$ & $0.12 \pm 0.09$ & $0.10 \pm 0.06$ \\
\hline Phosphates & $\left(\mathrm{mg} \mathrm{L}^{-1}\right)$ & $0.11 \pm 0.16$ & $0.03 \pm 0.01$ & $0.23 \pm 0.10$ & $0.42 \pm 0.23$ \\
\hline \multicolumn{6}{|c|}{ Biotic factors } \\
\hline Chlorophyll $a$ & $\left(\mu \mathrm{g} \mathrm{L}^{-1}\right)$ & $11.74 \pm 18.04$ & $10.63 \pm 5.35$ & $11.59 \pm 4.25$ & $12.61 \pm 7.16$ \\
\hline Cyanobacterial chlorophyll $a$ & $\left(\mu \mathrm{g} \mathrm{L}^{-1}\right)$ & $6.9 \pm 15.9$ & $4.1 \pm 4.2$ & $9.2 \pm 3.8$ & $11.1 \pm 6.8$ \\
\hline \multicolumn{6}{|c|}{ Microcystin and biological activity of cells } \\
\hline MC concentration & $\left(\mu \mathrm{g} \mathrm{L}^{-1}\right)$ & $5.5 \pm 10.0$ & $3.3 \pm 2.6$ & $3.0 \pm 0.9$ & $2.4 \pm 0.7$ \\
\hline MC biological activity & $\left(\mu \mathrm{g} \mathrm{L}^{-1}\right)$ & $2.0 \pm 0.9$ & $2.2 \pm 0.8$ & $2.8 \pm 0.1$ & $2.5 \pm 0.3$ \\
\hline \multicolumn{6}{|c|}{ Microcystis genes } \\
\hline $\begin{array}{l}\text { 16S rRNA } \\
1.07 \times 10^{4} \pm 1.32 \times 10^{4}\end{array}$ & (copies $\mu \mathrm{L}^{-1}$ ) & $4.72 \times 10^{4} \pm 10.25 \times 10^{4}$ & $5.59 \times 10^{4} \pm 6.67 \times 10^{4}$ & $1.71 \times 10^{4} \pm 0.91 \times 10^{4}$ & \\
\hline$m c y \mathrm{~A}$ & (copies $\mu \mathrm{L}^{-1}$ ) & $7132.3 \pm 9406.8$ & $9275.6 \pm 12065.7$ & $167.6 \pm 177.8$ & $242.5 \pm 157.1$ \\
\hline
\end{tabular}

Values are average $\pm S D$. 
of ammonium increased and ranged between 0.1 and 0.31 $\mathrm{mg} \mathrm{L}^{-1}$. The phosphate concentrations ranged between 0.01 and $0.61 \mathrm{mg} \mathrm{L}^{-1}$ in July, with values higher than 0.1 $\mathrm{mg} \mathrm{L}^{-1}$ observed only on 16 July. In September, phosphate concentrations increased and ranged between 0.1 and 1.0 $\mathrm{mg} \mathrm{L}^{-1}$. Values higher than $0.2 \mathrm{mg} \mathrm{L}^{-1}$ were spread across the research area and were noted at stations 1, 4, 6 and 913 on 23 September and at stations 1-11 and 14 on 25 September (Tab. 1, see also Supplementary Material, S1 Dataset).

\section{Biotic factors}

\section{Phytoplankton characteristics}

Significantly higher concentrations of Chloa were revealed in July than in September, while differences between study regions were not significant (Tab. 2). In July, concentrations of Chloa $>10 \mu \mathrm{g} \mathrm{L}^{-1}$ were detected near the dam (stations 1-3 on 16 July and 1-5 on 18 July) (S1 Dataset, Fig. 1). The highest concentration was $72 \mu \mathrm{g} \mathrm{L}-$ 1 , which was at station no. 1 (16 July). Other values did not exceed $21 \mathrm{~g} \mathrm{~L} \mathrm{~L}^{-1}$ (S1 Dataset, Fig. 1). In September, higher Chloa values $\left(>10 \mu \mathrm{g} \mathrm{L}^{-1}\right)$ were likewise observed in the downstream section of the study area (at stations 1-
5 on both sampling nights) and at single points located in the upstream section of the study area (stations 7 and 10 on 23 September and station 12 on 25 September) (S1 Dataset, Fig. 1). The values never exceeded $26 \mu \mathrm{g} \mathrm{L}^{-1}$.

The concentration of Cya differed significantly between both months and regions (Tab. 2). The highest observed concentration $\left(60 \mu \mathrm{g} \mathrm{L}^{-1}\right)$ was noted at station no. 1 (16 July), but other values did not exceed $13 \mu \mathrm{g} \mathrm{L}^{-1}$ (S1 Dataset, Fig. 1). In September, concentrations of Cya $>10$ $\mu \mathrm{g} \mathrm{L}^{-1}$ were observed only near the dam (stations 1-5 and 7 ), with the exception of a single point in the upstream section of the study area on 25 September (station 12) (S1 Dataset, Fig. 1). The values never exceeded $24 \mu \mathrm{g} \mathrm{L}^{-1}$. However, based on the proportion of Cya relative to Chloa, cyanobacteria were the dominant phytoplankton $(>50 \%)$ in July only at stations no. 1-3, whereas in September, all investigated stations were characterized by cyanobacterial dominance, which reached $93 \%$ at station no. 2 on 25 September (S1 Dataset, Fig. 1).

Microcystis aeruginosa and Aphanizomenon flos-aquae dominated in cyanobacteria assemblage and constituted approximately $70 \%$ and $30 \%$ of cyanobacteria in the samples from July, respectively. In September, the share of $M$. aeruginosa slightly decreased and amounted to about $60 \%$.

Tab. 2. Results of a two-way ANOVA testing of the effects of season and location within the study area on the changes in PC1 and PC2 values and the effects of selected parameters: chlorophyll $a$, cyanobacterial chlorophyll $a$, and microcystin concentrations at Sulejow Reservoir, Central Poland.

\begin{tabular}{|c|c|c|c|c|}
\hline Overal effect & df & F-ratio & P-value & Tukey, post-hoc \\
\hline \multicolumn{5}{|l|}{ PC1 } \\
\hline Regions & 1,52 & 64.69 & $<0.001$ & Dwnstr. > Upstr. \\
\hline Months & 1,52 & 285.21 & $<0.001$ & Jul. < Sep. \\
\hline Regions $\mathrm{x}$ months & 1,52 & 5.83 & $<0.05$ & \\
\hline \multicolumn{5}{|l|}{ PC2 } \\
\hline Regions & 1,52 & 34.68 & $<0.001$ & Dwnstr. $<$ Upstr. \\
\hline Months & 1,52 & 27.15 & $<0.001$ & Jul. < Sep. \\
\hline Regions $\mathrm{x}$ months & 1,52 & 4.25 & $<0.05$ & \\
\hline \multicolumn{5}{|l|}{ Chloa } \\
\hline Regions & 1,52 & 2.19 & $>0.05$ & \\
\hline Months & 1,52 & 33.96 & $<0.001$ & Jul. > Sep. \\
\hline Regions x months & 1,52 & 0.55 & $>0.05$ & \\
\hline \multicolumn{5}{|l|}{ Суа } \\
\hline Regions & 1,52 & 43.85 & $<0.001$ & Dwnstr. $>$ Upstr. \\
\hline Months & 1,52 & 51.40 & $<0.001$ & Jul. $<$ Sep. \\
\hline Regions x months & 1,52 & 6.26 & $<0.05$ & \\
\hline \multicolumn{5}{|l|}{$\mathrm{MC}$} \\
\hline Regions & 1,52 & 37.42 & $<0.001$ & Dwnstr. > Upstr. \\
\hline Months & 1,52 & 0.20 & $>0.05$ & \\
\hline Regions x months & 1,52 & 9.75 & $<0.05$ & \\
\hline
\end{tabular}


The size of the M. aeruginosa colony ranged from $100 \mu \mathrm{m}$ to even $2 \mathrm{~cm}$, but double and single cells that might be ingested by daphnids were also observed. The size of $A$. flosaquae filaments was $0.5-2.2 \mathrm{~cm}$.

\section{Microcystin-producing cyanobacteria}

Genotypes (16S rRNA) and toxic genotypes ( $m c y \mathrm{~A})$ of the cyanobacteria genus Microcystis were found in all analyzed samples in both July and September (with only one exception, station 9 on 18 July). The number of $16 \mathrm{~S}$ rRNA gene copies ranged from approx. $10^{3}-10^{5}$ in July, with the higher values $\left(>2 \times 10^{4}\right.$ gene copies) usually found in the downstream section of the study area (at stations 14 and 14 on 16 July and at stations $1-6,8,10$ and 13 on 18 July) (S1 Dataset, Fig. 1). The quantity of the observed number of gene copies was positively related to the $\mathrm{MC}$ concentrations ( $\mathrm{r}=0.69$; $\mathrm{e}<0.05$ and $\mathrm{r}=0.443 ; \mathrm{P}<0.05$ for 16sRNA and $m c y$ A, respectively) and were significantly higher in July than in September $(\mathrm{t}=2.60 ; \mathrm{e}=0.012 ; \mathrm{df}=54$ and $\mathrm{t}=5.66 ; \mathrm{P}<0.001 ; \mathrm{df}=54$, for 16 sRNA and $m c y \mathrm{~A}$, respectively). In September, the highest number of gene copies $\left(>2 \times 10^{4}\right)$ were found in the downstream section (stations 1-4) (S1 Dataset, Fig. 1). In the case of the mcyA gene, similar to the patterns observed for the 16S rRNA gene, high numbers of gene copies $\left(>1 \times 10^{4}\right)$ and a high variability in the number of gene copies were observed in July (particularly on 18 July) (S1 Dataset, Fig. 1). In September, the number of mcyA gene copies never exceeded $5 \times 10^{2}$. In both July and September, the highest observed numbers of mcyA gene copies were found near the dam (stations 1-4), with the exception of those from 25 September, when the highest numbers were observed between the downstream and upstream sections of the study area (stations 6 and 7) (S1 Dataset, Fig. 1).

\section{Microcystin concentration and their biological activity}

Only intracellular MC-RR, MC-YR and MC-LR were detected by HPLC in all analyzed samples from 16 and 18 July and 23 and 25 September (S1 Dataset, Fig. 1). Their concentrations were significantly higher in the downstream study area than in the upstream one, while differences between months were not significant (Tab. 2). Concentrations of total MCs greater than $4 \mu \mathrm{g} \mathrm{L}^{-1}$ were observed in July at the downstream section of the study area (stations 1-3 on 16 July and stations 1-5 on 18 July), with a maximum of $38.65 \mu \mathrm{g} \mathrm{L}^{-1}$, which was found at station no. 1 (16 July) (S1 Dataset, Fig. 1). Concentrations of MCs in a range from 1 to $4 \mu \mathrm{g} \mathrm{L}^{-1}$ were found at stations 4-10 (16 July) and 4-8, 10, 12, and 13 (18 July). Concentrations below $1 \mu \mathrm{g} \mathrm{L}^{-1}$ were detected at stations 12-14 (16 July) and 9, 11 and 14 (18 July) (S1 Dataset, Fig. 1). In September, the concentrations of MCs ranged from 2-5 $\mu \mathrm{g} \mathrm{L}^{-1}$ on 23 and 1-4 $\mu \mathrm{g} \mathrm{L}^{-1}$ on 25 September.
The highest concentrations of total MCs $\left(3.00 \mu \mathrm{g} \mathrm{L}^{-1}\right.$ and $2.36 \mu \mathrm{g} \mathrm{L}^{-1}$ ) were observed in the downstream study section (stations 1-6) on 23 and 25 September, respectively (S1 Dataset, Fig. 1).

In all analyzed samples, toxic equivalents of MCs were found (PPIA analysis), but the biological activity varied between July and September. Overall in the case of 35 out of the 56 analyzed samples, the biological activity of MCs in the cyanobacterial cells (intracellular MCs) expressed as the concentration of MCs inhibiting the PP2A enzyme was shown to be higher than $2.5 \mu \mathrm{g} \mathrm{dm}$ ${ }^{3}$, which was the upper limit for detection with the MicroCystest. In July, values above the test limit were found at the downstream study section (stations 1-5 on 16 July and stations 1-6 on 18 July) (S1 Dataset, Fig. 1). In September, the biological activity of MCs was $>2.5 \mu \mathrm{g} \mathrm{L}^{-1}$ in almost all analyzed samples. On 25 September, the values for MC biological activity decreased in the upstream section of the study area (stations 11-14, but still ranged from 2$2.5 \mu \mathrm{g} \mathrm{L}^{-1}$ ) (S1 Dataset, Fig. 1).

\section{Zooplankton characteristics}

Based on their ecological requirements and role in freshwater ecosystems (Woodward and Warren, 2007), three distinct groups of zooplankton species were classified:

a) large filter feeders ( $>1 \mathrm{~mm}$ body length) consisting of Eudiaptomus vulgaris (Schmeil, 1896) (body length ranged from 1.2 to $1.3 \mathrm{~mm}$ ), Diaphanosoma brachyurum (Liévin, 1848) (1-1.3 mm) and three species of Cladocera from the Daphnia longispina group: $D$. longispina (O.F. Müller, 1776), D. galeata (Sars, 1864) (the range of body length for two species: 1.2$1.5 \mathrm{~mm}$ ) and D. hyalina (Leydig, 1860) $(1.1-1.4 \mathrm{~mm}$ ).

b) small filter feeders ( $\leq 1 \mathrm{~mm}$ body length) consisting of Daphnia cucullata (Sars.), Bosmina coregoni (Baird) $(0.2-0.3 \mathrm{~mm})$, B. longirostris (O.F. Müller) (0.3-0.6 $\mathrm{mm}$ ), and Chydorus sphaericus (O.F. Müller) (0.1-0.2 $\mathrm{mm})$.

c) predatory zooplankton, including Leptodora kindtii (Focke) (1.2-6 mm) and carnivorous species of $\mathrm{Cy}$ clopoida (1-1.5 mm).

The composition and abundance of zooplankton species changed between the sampling months (Figs. 2 and 3). The density and biomass of all groups were higher in July than in September $(\mathrm{t}=3.23 ; \mathrm{P}<0.01 ; \mathrm{df}=54$ and $\mathrm{t}=2.78 ; \mathrm{P}<0.01$; $\mathrm{df}=54$, respectively). The differences in the spatial distribution of zooplankton were also more evident in July. Predatory zooplankton were most abundant near the dam (stations 1-2) and between the downstream and upstream sections of the study area (stations 6 and 7) on 16 July. On 16 July, the high density and biomass of large filter feeders were observed in the upstream study section (stations 1114 ), whereas the small filter feeders were dominant between the downstream and upstream sections of the study 
area (station 6). On 18 July, the highest density and biomass of small filter feeders were detected, with the maximum peak occurring in the upstream section (station 14). However, the density of large filter feeders was lower than it was on 16 July ( $\mathrm{t}=2.18 ; \mathrm{P}<0.05 ; \mathrm{df}=26$ ), and minimal values were found in the upstream study section (stations 1214). The density of small filter feeders was higher in July than in September $(\mathrm{t}=6.64 ; \mathrm{P}<0.001 ; \mathrm{df}=54)$, while no significant differentiation was found in the biomass. Generally, the density and biomass of large filter feeders were higher in September than in July ( $\mathrm{t}=8.67 ; \mathrm{P}<0.001 ; \mathrm{df}=54$ and $\mathrm{t}=2.38 ; \mathrm{P}<0.05 ; \mathrm{df}=54$, respectively). The relatively high, for this time of the year, density and biomass of large filter feeders at all sampling stations were the most prominent aspects of the spatial distribution pattern for zooplankton in September (Fig. 3).

The biomass of small filter feeders was negatively correlated with the abundance of cyanobacteria and with microcystin concentrations, while the biomass of large filter feeders was negatively correlated with microcystin concentrations and with 16S rRNA gene fragments (Tab. 3).

\section{Fish stock dynamics}

In July 2013, the numerical density of fish was highly variable across the 14 sampling points, changing from less than 100 fish ha ${ }^{-1}$ to nearly 3500 fish ha ${ }^{-1}$. On 16 July, the average density was $708 \pm 983$ fish ha $^{-1}$. Two areas of higher fish density were detected, one with densities of over 2000 fish ha ${ }^{-1}$ (station 5) and the second with densities of over 3000 fish ha $^{-1}$ (station 8), i.e. fish were concentrated in the central section of the study area. However, a high-density area was also located close to the dam along the second hydroacoustic transect, with densities of over 700 fish ha $^{-1}$ (stations 2 and 3). The area of high fish density at stations 2 and 3 spatially overlapped with those stations where the highest MC levels were recorded. On 18 July, the average density was much lower $\left(293 \pm 297\right.$ fish ha $\left.^{-1}\right)$, with the highest density in the downstream study section occurring at point $3\left(1080\right.$ fish ha $\left.^{-1}\right)$ and at station no. 7, where the second highest density was found (730 fish ha ${ }^{-1}$ ). However, the differences between nights were not significant $(t=1.71$; $\mathrm{P}=0.1$ ). In September, the spatial distribution of fish was similar on both sampling nights $\left(23^{\text {rd }}\right.$ and $\left.25^{\text {th }}\right)$, with the

a)

16 July

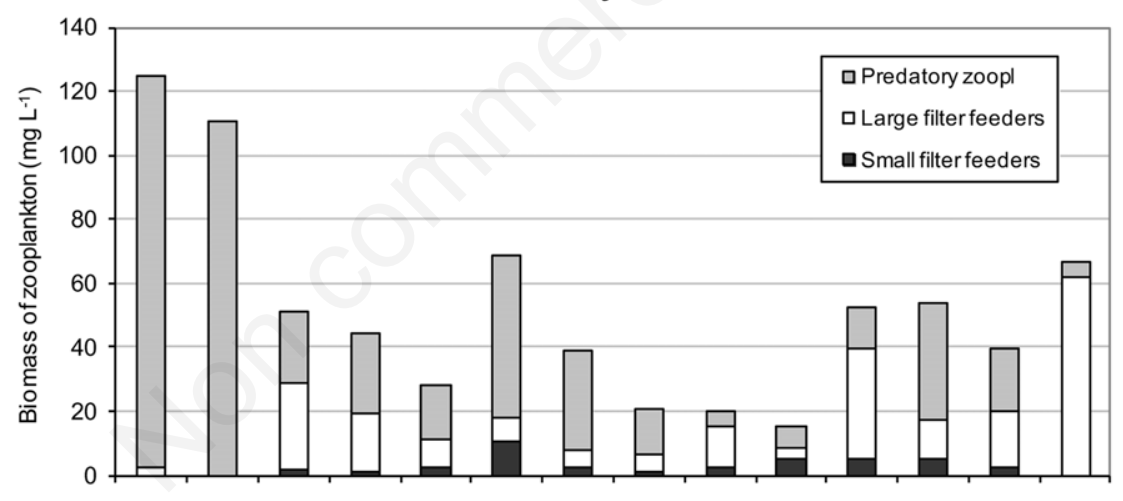

b)

18 July

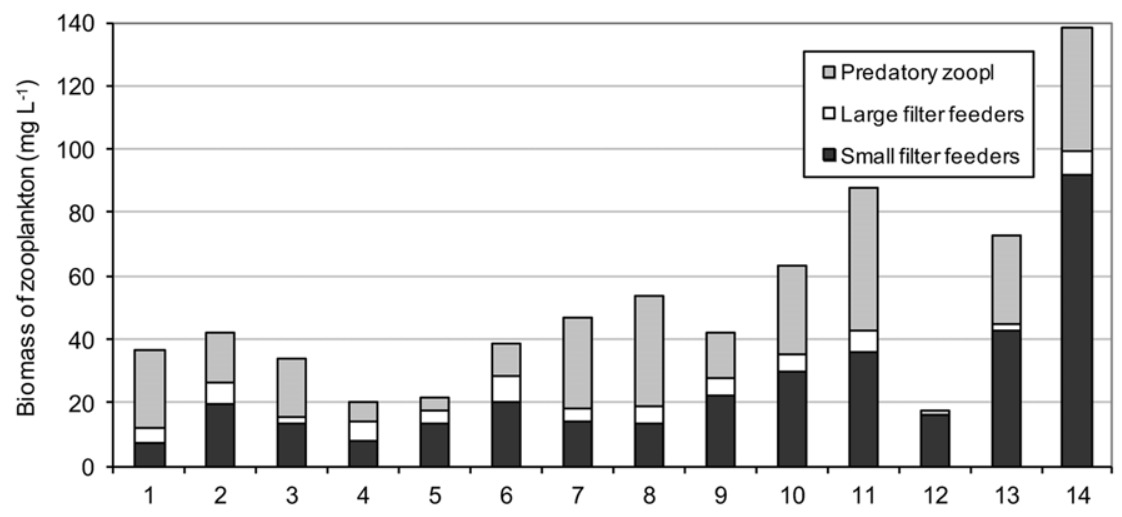

Fig. 2. Dynamics of the zooplankton biomass at the fourteen stations on 16 July (a) and 18 July 2013 (b) at Sulejow Reservoir, Central Poland. 
highest fish densities (597 fish ha ${ }^{-1}$ on 23 September and 1498 fish $\mathrm{ha}^{-1}$ on 25 September, both at station number 5) observed in the central section of the study area. However, the average fish density was significantly higher on $25 \mathrm{Sep}$ tember than on 23 September $(\mathrm{t}=2.91 ; \mathrm{P}<0.01$; $\mathrm{df}=26)$. In summary, the highest numerical densities of fish were observed in the central section of the study area (stations 5, 7 and 8), with the one exception noted above for 18 July. Both fish biomass and density were negatively correlated with large filter feeders, while no significant correlation with small filter feeders and predatory zooplankton was found (Tab. 3).

The dominant fish species at the upstream gillnetting site was $R$. rutilus, which accounted for over $60 \%$ and $40 \%$ of the specimens caught in July and September, respectively. Breams were more frequent at the downstream gillnetting site, where $B$. bjöerkna and $A$. brama made up nearly $70 \%$ of the catch in July and $50 \%$ in September. Other frequently observed fish species were G. cernua, which were found at the downstream gillnetting site in July, and A. alburnus, which were found at the upstream gillnetting site in September. Approximately ten times fewer fish were caught at the downstream gillnetting site (Tab. 4, S2 Dataset).

\section{Abiotic-biotic interactions}

A PCA analysis of the physico-chemical and cyanobacteria-related variables revealed two principal components with eigenvalues larger than one, which explained almost $76 \%$ of the observed variance (Tab. 5).

Parameters such as oxygen concentration, $\mathrm{pH}$, cyanobacteria abundance and phosphate concentrations were positively correlated with PC1, while temperature and the concentration of nitrates and nitrites were strongly and negatively correlated with this axis. In turn, microcystin concentrations and biological activity markers (number of 16S rRNA and mcyA gene fragments) were the main (negative) contributors to PC2 (Fig. 4; Tab. 5).

Fish abundance was negatively correlated with both principal components: $\mathrm{r}=-0.33(\mathrm{P}<0.05)$ and $\mathrm{r}=-0.32$ $(\mathrm{P}<0.05)$ for $\mathrm{PC} 1$ and $\mathrm{PC} 2$, respectively. Fish abundance tended to decrease at stations with lower abundance of cyanobacteria and increase at stations with higher con-

a)

23 September

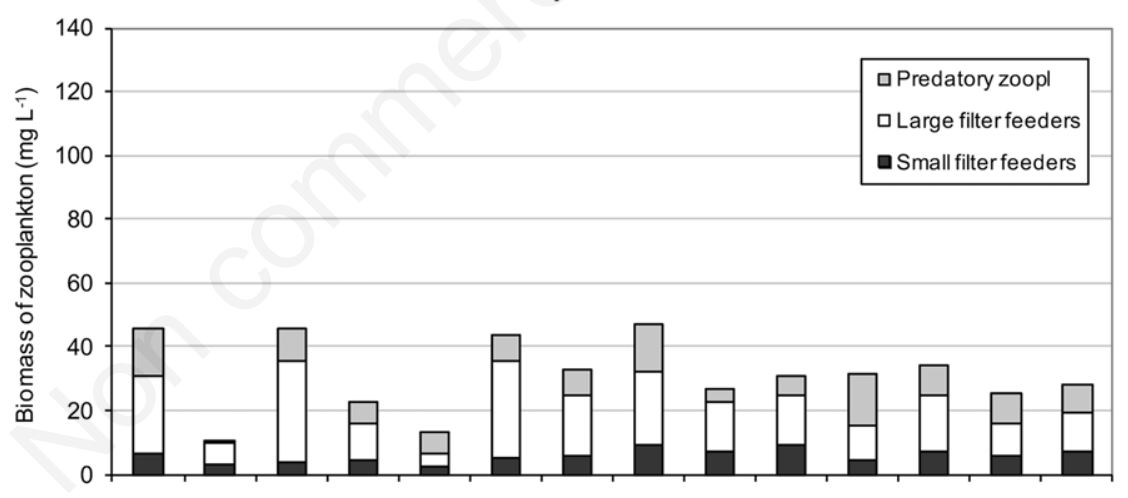

b)

25 September

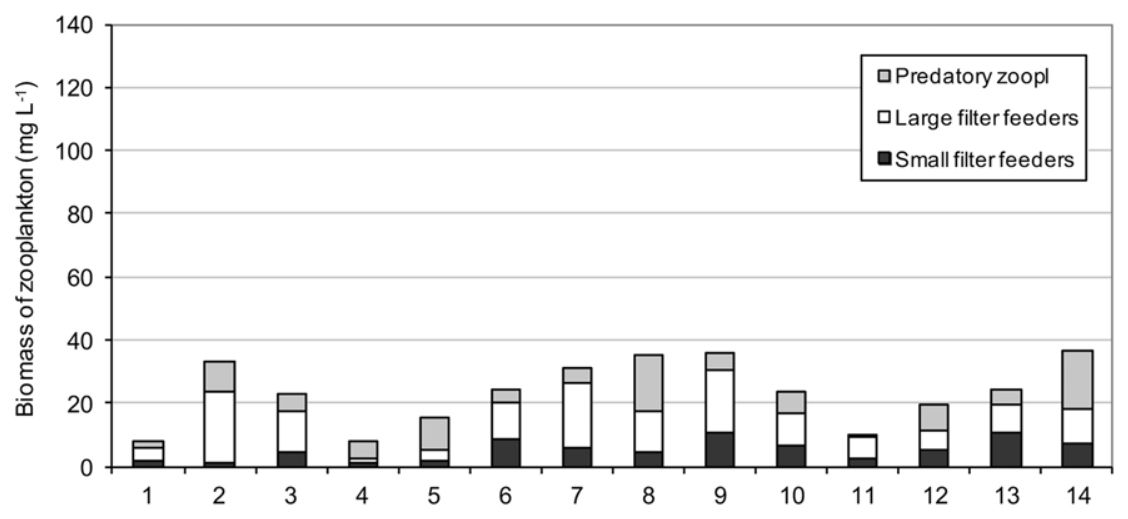

Fig. 3. Dynamics of the zooplankton biomass at the fourteen stations on 23 September (a) and 25 September 2013 (b) at Sulejow Reservoir, Central Poland. 
centrations of nitrates and nitrites (associated with the $\mathrm{PC} 1$ axis) and with growing $\mathrm{MC}$ concentrations and toxic genotype levels (associated with the PC2 axis).

The biomass of large filter feeders was not significantly correlated with $\mathrm{PC} 1(\mathrm{r}=0.04 ; \mathrm{P}>0.05)$; however, it was positively correlated with $\mathrm{PC} 2(\mathrm{r}=0.42 ; \mathrm{P}<0.05)$. The biomass of large filter feeders decreased along with increasing MC concentration and genotype numbers (associated with the PC2 axis). The correlation between the densities of fish and the biomass of large filter feeders was negative and statistically significant $(\mathrm{r}=-0.50 ; \mathrm{P}<0.05)$.

PC1 and PC2 values differed significantly in both spatial and temporal dimensions (Tab. 4). For PC1, higher values were found in September than in July and in the downstream section than in the upstream section of the study area. For PC2, higher values were found in September and in the upstream section of the study area.

\section{DISCUSSION}

In the Sulejow Reservoir, the presence of toxigenic strains of cyanobacteria is observed annually; however, their abundance varies between growing seasons (Izydorczyk and Tarczyńska, 2005; Izydorczyk et al., 2009; Gągała et al., 2014). The summer months of 2013 were

Tab. 3. The correlations matrix for analyzed biological parameters at Sulejow Reservoir, Central Poland (values significant at $\mathrm{P}<0.05$ are in bold).

\begin{tabular}{|c|c|c|c|c|c|c|c|c|c|c|c|}
\hline & MCs & Cya & Chloa & 16S rRNA & $m c y A$ & Total zoopl. & S filtr. & L filtr. & Pred. zoopl. & Fish $\mathbf{N}$ & Fish B \\
\hline $\mathrm{MCs}$ & 1.000 & & & & & & & . & & & \\
\hline Cya & 0.656 & 1.000 & & & & & & 7 & & & \\
\hline Chloa & 0.714 & 0.891 & 1.000 & & & & & & & & \\
\hline $16 \mathrm{~S}$ rRNA & 0.687 & 0.321 & 0.523 & 1.000 & & & & & & & \\
\hline$m c y \mathrm{~A}$ & 0.443 & -0.023 & 0.190 & 0.624 & 1.000 & & & & & & \\
\hline Total zoopl. & 0.196 & -0.146 & -0.014 & 0.124 & 0.080 & 1.000 & & & & & \\
\hline S filtr. & -0.315 & -0.372 & -0.306 & -0.121 & -0.244 & 0.423 & 1.000 & & & & \\
\hline L filtr. & -0.294 & -0.161 & -0.388 & -0.301 & -0.180 & -0.069 & -0.125 & 1.000 & & & \\
\hline Pred. zoopl. & 0.208 & -0.157 & 0.012 & 0.177 & 0.260 & 0.833 & 0.132 & -0.103 & 1.000 & & \\
\hline Fish N & 0.164 & -0.123 & 0.062 & 0.062 & 0.430 & 0.047 & -0.173 & -0.392 & 0.230 & 1.000 & \\
\hline Fish B & 0.064 & -0.187 & 0.036 & 0.119 & 0.315 & 0.102 & 0.046 & -0.498 & 0.241 & 0.782 & 1.000 \\
\hline
\end{tabular}

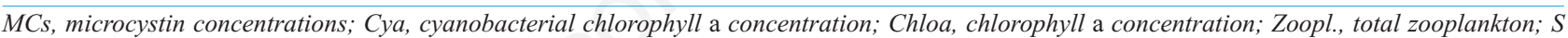
filtr, small filter feeders; L filtr, large filter feeders; Pred. zoopl., predatory zooplankton; Fish N, numerical abundance of fish; Fish B, biomass of fish.

Tab. 4. Dominance of fish species in the gillnet catch with respect to the cyanobacterial chlorophyll $a$ concentration at Sulejow Reservoir, Central Poland (dominant factors in bold).

\begin{tabular}{|c|c|c|c|c|}
\hline Location of gillnets (station number) & 9 & 3 & 12 & 5 \\
\hline Cyanobacterial chlorophyll $a$ concentration & Lower & Higher & Lower & Higher \\
\hline Catch data & \multicolumn{2}{|c|}{17 July } & \multicolumn{2}{|c|}{24 September } \\
\hline & \multicolumn{2}{|c|}{$\mathrm{D}(\%)$} & \multicolumn{2}{|c|}{ D $(\%)$} \\
\hline Asp Aspius aspius & 1.57 & & 2.11 & \\
\hline Ruffe Gymnocephalus cernua & & 23.08 & 2.11 & \\
\hline Carp Cyprinus carpio & 1.57 & & & \\
\hline Silver bream Blicca bjoerkna & 14.17 & 46.15 & 11.27 & 9.52 \\
\hline Common bream Abramis brama & 14.17 & 23.08 & 7.04 & 38.10 \\
\hline Eurasian perch Perca fluviatilis & 3.94 & & 2.82 & 14.29 \\
\hline Roach Rutillus rutillus & 61.42 & & 40.85 & 23.81 \\
\hline Pikeperch Stizostedion lucioperca & 0.79 & 7.69 & 1.41 & 14.29 \\
\hline Bleak Alburnus alburnus & 2.36 & & 32.39 & \\
\hline Tot $\mathrm{n}$. & 127 & 13 & 142 & 21 \\
\hline
\end{tabular}

D, dominance. 
characterized by Chloa generally below $20 \mu \mathrm{g} \mathrm{L}^{-1}$, which according to Xu et al. (2015) is referred to as a sub-bloom period. The analysis indicated temporal, i.e. from July to September, but no spatial differentiation of total phytoplankton abundance (measured as the Chloa). However, both spatial (toward the dam) and temporal (from July to September) increases in cyanobacterial abundance were observed (Tab. 2). In turn, the concentration of MCs presented a spatial pattern similar to that of cyanobacteria, although without any temporal differentiation (Tab. 2) and even though significantly higher concentrations of toxic genotypes of cyanobacteria were found in July ( $\mathrm{P}<0.001$ for $m c y$ A). Similar relationships have previously been observed in the Sulejow Reservoir, when, due to a decrease in Microcystis biomass as a result of poor growing conditions (short retention time), the amount of toxic genotypes increased (Gągała et al., 2014). In 2013, the cause of the observed phenomena could be analogous, because the reported retention time was almost twice as short in July as it was in September (18.8 and 23.1 days on 16 and 18 July and 32.4 and 34.0 days on 23 and 25 September, respectively; data from The Regional Water Management Authority in Warsaw, www.warszawa.rzgw.gov.pl). A statistical analysis also demonstrated that both the abundance of cyanobacteria and MC concentrations were higher in the downstream section of the study area than in the upstream section (Tab. 2). Such an uneven distri-

Tab. 5. Results of a PCA analysis of environmental factors considered as potentially influencing the distribution of fish and zooplankton in Sulejow Reservoir, Central Poland. Correlations higher than 0.7 are in bold.

\begin{tabular}{lcc} 
Variables & \multicolumn{2}{c}{ Factors loadings } \\
& $\mathrm{PC}$ & $\mathrm{PC} 2$ \\
\hline Temperature & $\mathbf{- 0 . 7 9 1}$ & -0.531 \\
\hline Oxygen & $\mathbf{0 . 9 3 2}$ & -0.152 \\
\hline $\mathrm{pH}$ & $\mathbf{0 . 8 6 0}$ & 0.124 \\
\hline $\mathrm{NO}_{3}$ & $\mathbf{- 0 . 9 0 7}$ & -0.147 \\
\hline $\mathrm{NO}_{2}$ & $\mathbf{- 0 . 7 3 6}$ & -0.192 \\
\hline $\mathrm{NH}_{4}$ & 0.646 & 0.245 \\
\hline $\mathrm{PO}_{4}$ & $\mathbf{0 . 7 4 6}$ & 0.103 \\
\hline $\mathrm{MCs}$ & 0.439 & $\mathbf{- 0 . 8 0 1}$ \\
\hline Cya & $\mathbf{0 . 8 9 1}$ & -0.367 \\
\hline Chloa & 0.656 & -0.623 \\
\hline $16 \mathrm{~S}$ rRNA & 0.060 & $\mathbf{- 0 . 8 8 4}$ \\
\hline mcyA & -0.313 & $\mathbf{- 0 . 7 8 5}$ \\
\hline Eigenvalues & 6.09 & 3.01 \\
\hline \% total variance & 50.74 & 25.10 \\
\hline Cumulative \% & 50.74 & 75.84 \\
\hline MCs, microcystin concentrations; Cya, cyanobacterial chlorophyll a \\
concentration; Chloa, chlorophyll a concentration.
\end{tabular}

bution of cyanobacteria between the downstream (sites 17) and upstream (sites 8-14) sections of our research area has previously been reported as the characteristic state of this ecosystem (Wagner et al., 2009). The reason for this is the strength and direction of the wind-induced currents. Izydorczyk and Tarczyńska (2005) showed that the constant westerly and southwesterly winds, which usually dominate in the vicinity of the reservoir, result in the drifting of the bloom toward the dam area.

The high abundance of cyanobacteria in the downstream section of the reservoir, resulting in intensive cyanobacterial photosynthesis, influenced the high oxygen concentration and alkaline $\mathrm{pH}$ (Fig. 4). Our study showed that the distribution of cyanobacteria did not always reflect the availability of dissolved forms of nutrients. In particular, nitrates and nitrites were negatively correlated with the abundance of cyanobacteria (Fig. 4). It is well known that cyanobacteria do not have to rely on soluble forms of nitrogen, because some species can absorb it from the air (e.g., Aphanizomenon sp.). Nevertheless, in our case, the dominant cyanobacteria genus was Microcystis, in which heterocysts (nitrogen binding cells) are not observed. According to Walker (2014), the growth of Microcystis strains is more positively associated with ammonium concentration than with that of nitrates. In contrast, a positive correlation was observed between cyanobacteria abundance and phosphate concentration

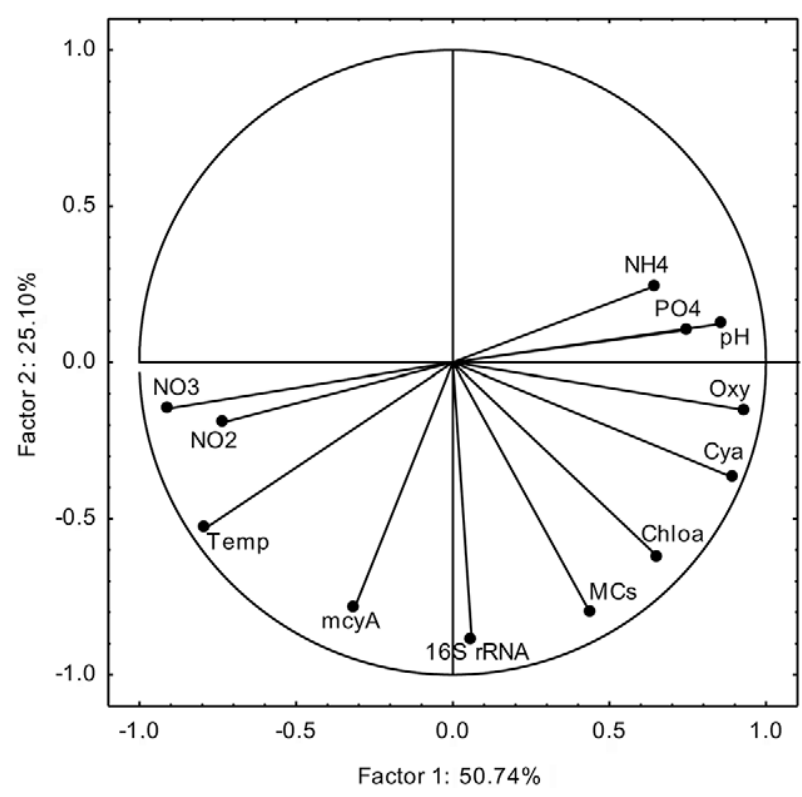

Fig. 4. PCA analysis of environmental factors considered as potentially influencing the distribution of fish and zooplankton in Sulejow Reservoir, Central Poland. Temp (temperature), Oxy (oxygen), MCs (microcystin concentrations), Cya (cyanobacterial chlorophyll $a$ concentration), Chloa (chlorophyll $a$ concentration). 
(Fig. 4). This finding is consistent with the reports of other authors (Vézie et al., 2002; Davis et al., 2009).

Several studies have revealed that toxic cyanobacteria influence zooplankton species composition and these reports have also shown that high MC concentrations are negatively correlated with Daphnia and calanoid copepod abundance, but are positively correlated with small, relatively inefficient phytoplankton feeders, such as Bosmina, rotifers and also with cyclopoid copepods (Hansson et al., 2007; Sun et al., 2012). Our results indicated that the biomass of both large and small filter feeders was significantly negatively correlated with microcystin concentrations, but contrary to our literature-based expectations (Hansson et al., 2007; Sun et al., 2012), it was not the large forms of zooplankton but the small filter feeders that were negatively correlated with the abundance of cyanobacteria (the concentration of Cya). Both daphniids and herbivorous copepods are potential consumers of cyanobacterial cells, but they generally avoid cyanobacteria, because it is a low-quality food item (MartinCreuzburg et al., 2008; Schwarzenberger et al., 2010). Copepods use multiple chemosensory signals in detecting toxins and avoiding their ingestion (Ger et al., 2011). In contrast, cladocerans are generalist and non-selective grazers; thus, they are more vulnerable to intracellular toxins. Therefore, daphniids have developed various adaptations against the harmful effects of cyanobacteria (Ger et al., 2014), including behavioral responses that consist of avoiding areas with cyanobacterial blooms (Fulton and Paerl, 1987; Roy, 2008; Reichwaldt et al., 2013) and the physiological detoxification of ingested compounds (Pflugmacher et al., 1998). Our results indicate that large filter feeders were negatively correlated with the abundance of cyanobacteria genus Microcystis (number of 16sRNA gene copies), but results in respect to the relationship between zooplankton and biological activity of cyanobacteria were inconclusive (zooplankton correlation with PC2 axis, Tab. 3). Wojtal-Frankiewicz et al. (2014) demonstrated that daphniids in the Sulejow Reservoir have effective antioxidant mechanisms that protect them against the toxic effects of MCs. We assumed that this physiological response would allow daphniids to coexist with a high biomass of toxic cyanobacteria. Thus, in sub-bloom conditions another relationship, interaction between the zooplankton filter feeders and fish (both biomass and numerical abundance), might be an important factor causing spatial heterogeneity in zooplankton community dynamics. Adult specimens of large-bodied species such as Daphnia are an attractive food source for planktivorous fish, and this effect was reflected in the negative correlation between the biomasses of fish and large filter feeders $(\mathrm{r}=-0.50, \mathrm{P}<0.05)$. We presume that temporal diversity in the composition and abundances of zooplankton communities, which were observed between 16 and
18 July (Fig. 2), could also be a consequence of fish pressure. On 16 July, the areas of higher fish density and zooplankton were grouped in the upstream section of the study area. Fish impact on large-bodied individuals of zooplankton could promote small filter feeders by competitive release, which resulted in an increase in their abundance on 18 July (Fig. 2 a, b). Additionally, it is worth noting that the downstream gillnetting site was dominated by common bream and white bream that are more effective zooplanktivorous than the roach dominating at upstream gillnetting stations (van den Berg, 1993). The strength of the relationship between fish and the small filter feeders was insignificant, which is in accordance with the results of classical limnological research (review by Lazzaro, 1987).

The earlier observations of Wojtalik et al. (2006) in the Sulejow Reservoir indicate that after a bloom develops in the downstream section of the reservoir, fish tend to avoid the bloom-affected area and move upstream. Similar results related to avoidance behaviors were obtained in Lake Ammersee by Ernst (2008), who reported that whitefish tended to migrate to deeper water during the summer bloom to avoid the presence of Planktothrix rubescens. In both of these cases, the concentrations of cyanobacteria were much higher than those observed in our current study. Mastin et al. (2002) showed in experimental studies that fish avoid areas with cyanobacteria where chlorophyll $a$ concentrations were $175 \mu \mathrm{g} \mathrm{L}^{-1}$, but not areas with lower concentrations. In the present study, the maximal Chloa was $72.31 \mu \mathrm{g} \mathrm{L}^{-1}$ and there was no correlation between fishes and chlorophyll concentrations.

It is interesting that, according to our PCA results, fish responded negatively to the increased abundance but not the increased biological activity of cyanobacteria. In experimental studies, Phillips et al. (1985) and Tencalla et al. (1994) demonstrated a lack of toxic effects on salmonids, which are less tolerant than cyprinids, when immersed in water with cyanotoxins. Only intraperitoneal injections or oral gavage of the cyanotoxins were harmful for salmonids. In the Sulejow Reservoir, only intracellular toxins were detected, which could affect fish only after the cyanobacterial cells are consumed. In our study, cyanobacteria cells did not enter the digestive tracts of fish, because there were no phytoplanktivorous fish species in the reservoir. Nevertheless, the direct consumption of cyanobacteria is not the only pathway for toxin bioaccumulation, as demonstrated in Eurasian perch in Lake Bourget. Although the fish and $P$. rubescens occupied different parts of the lake (epilimnion $v$. metalimnion), and the fish had no opportunity for direct contact with toxic cells, MCs were detected in their muscles and liver, where they probably accumulated as a result of foraging on MC-containing Daphnia (Sotton et al., 2012). However, previous analyzes of the stomach contents of fish inhabiting the Sulejow Reservoir have shown that, with the 
exception of the diets of juvenile fish, zooplankton make up only a small percentage of the food supply for most species (Frankiewicz et al., 2002). Finally, fish are able to detoxify or excrete ingested MCs, which allows them to mitigate the potential negative effect of toxins and tolerate the presence of blooms to a certain extent (Sahin et al., 1996; Malbrouck and Kestemont, 2006; Campos and Vasconcelos, 2010).

\section{CONCLUSIONS}

Reports on cyanobacteria, zooplankton and fish interaction in sub-bloom conditions are scarce, because only the excessive growth of cyanobacteria is usually considered a major threat to ecosystems. However, our study indicates a complex relationship between toxic cyanobacteria, smalland large-bodied zooplankton and fish in chlorophyll $a$ concentrations generally below $20 \mu \mathrm{g} \mathrm{L}^{-1}$. In dynamic ecosystems subjected to frequent toxic blooms, aquatic animals do not have to follow a predictable relationship proportional to cyanobacteria abundance, as has been demonstrated by Teegarden et al. (2008) for copepods. This is especially the case when aquatic animal organisms are regularly exposed to MCs, triggering development of toxinresistant physiological mechanisms (Wojtal-Frankiewicz et $a l ., 2014)$ that weaken known behavioral (Ernst, 2008; Roy, 2008) or life-trait (Fulton and Paerl, 1987) responses. Nevertheless, further studies of the interactions between cyanobacteria, zooplankton and fish in sub-bloom conditions seems to be important in the face of observed climate change, where higher temperatures promote the growth rate of toxic cyanobacteria to a greater degree than that of nontoxic strains (Davis et al., 2009). As a consequence, many presently bloom-free lakes might be susceptible to subbloom densities of toxic cyanobacteria in a near feature.

\section{ACKNOWLEDGMENTS}

The authors are grateful to all of the project participants and technical staff involved in the field measurements, particularly Sebastian Ratajski, Michał Wiązek, Kamil Dawidowicz and Tomasz Wójcicki. The authors would also like to thank Dr Jakub Pawełczyk from the Institute of Biological Medicine of the Polish Academy of Sciences for his assistance with the quantitative analysis of cyanobacteria via real-time PCR, and Professor Mirosław Przybylski from the Department of Ecology and Vertebrate Zoology, University of Lodz for his helpful comments on the statistical analysis.

This research was financially supported by the National Science Center, Poland (grant no. UMO2012/05/B/NZ9/00980, www.ncn.gov.pl) to Malgorzata Godlewska and by EnvEurope (grant no. LIFE08
ENV/IT/000339) to ERCE PAS. The funders had no role in the study design, data collection and analysis, decision to publish, or preparation of the manuscript.

\section{REFERENCES}

Amado LL, Monserrat JM, 2010. Oxidative stress generation by microcystins in aquatic animals: Why and how. Environ. Int. 36:226-235.

Amoros C, 1984. [Introduction Pratique a la Systematique des Organisms des Eaux Continentals Françaises: Crustacés Cladocéres]. [Article in French]. Extrait du Bulletin Mensuel de la Société Linnéenne de Lyon 53:3-4.

Baganz D, Staaks G, Pflugmacher S, Steinberg CEW, 2004. Comparative study of microcystin-LR-induced behavioural changes of two fish species, Danio rerio and Leucaspius delineatus. Environ. Toxicol. 19:564-570.

Balk H, Lindem T, 2011. Sonar4 and Sonar5-Pro Post Processing Systems. Operator manual version 6.01. Lindem Data Acquisition, Oslo (Norway).

Benzie JAH, 2005. The genus Daphnia (including Daphniopsis) (Anomopoda: Daphniidae), p. 1-374. In: H.J.F. Dumont (ed.), Guides to the Identification of the Macroinvertebrates of the Continental Waters of the World. Ghent: Kenobi Productions, Leiden: Backhuys Publishers.

Berthon JL, Brousse S, 1995. Modification of migratory behavior of planktonic Crustacea in the presence of a bloom of Microcystis aeruginosa (Cyanobacteria). Hydrobiologia 300/301:185-193.

Bishop C, Anet E, Gorham P, 1959. Isolation and identification of the fast-death factor in Microcystis aeruginosa NRC-1. Can. J. Biochem. Phys. 37:453-471.

Bottrell HH, Duncan A, Gliwicz ZM, Grygierek E, Herzig A, Hilbricht-Ilkowska A, Krasawa H, Larsson P, Weglenska T, 1976. A review of some problems in zooplankton production studies. Norw. J. Zool. 24:419-456.

Campos A, Vasconcelos V, 2010. Molecular Mechanisms of Microcystin Toxicity in Animal Cells. Int. J. Mol. Sci. 11: 268-287.

Cazenave J, Wunderlin DA, Bistoni MA, Am'e MV, Krause E, Pflugmacher S, Wiegand C, 2005. Uptake, tissue distribution and accumulation of Microcystin-RR in Corydoras paleatus, Jenynsia multidentata and Odontesthes bonariensis. Aquat. Toxicol. 75:178-190.

Chen J, Xie P, Li L, Xu J, 2009. First identification of the hepatotoxic microcystins in the serum of a chronically exposed human population together with indication of hepatocellular damage. Toxicol. Sci. 108 81-89.

Chen J, Xie P, Zhang DW, Ke ZX, Yang H, 2006. In situ studies on the bioaccumulation of microcystins in the phytoplanktivorous silver carp (Hypophthalmichthys molitrix) stocked in Lake Taihu with dense toxic Microcystis blooms. Aquaculture 261:1026-1038.

DeMott WR, Gulati RD, VanDonk E, 2001. Daphnia food limitation in three hypereutrophic Dutch Lakes: evidence for exclusion of large-bodies species by interfering filaments of cyanobacteria. Limnol. Oceanogr. 46:2054-2060.

Davis TW, Berry DL, Boyer GL, Gobler CJ, 2009. The effects of temperature and nutrients on the growth and dynamics of 
toxic and non-toxic strains of Microcystis during cyanobacteria blooms. Harmful Algae 8:715-725.

Drastík V, Kubecka J, Cech M, Frouzova J, Riha M, Juza T, Tuser M, Jarolím O, Prchalova M, Peterka J, Vasek M, Kratochvíl M, Matena J, Mrkvicka T, 2009. Hydroacoustic estimates of fish stocks in temperate reservoirs: day or night surveys? Aquat. Living Resour. 22:69-77.

Ernst B, 2008. Investigations on the impact of toxic cyanobacteria on fish - as exemplified by coregonids in Lake Ammersee. PhD Dissertation, University of Konstanz. Available from: http://kops.uni-konstanz.de/handle/123456789/6546.

Foote KG, Knudsen HP, Vestnes G, Maclennan DN, Simmonds EJ, 1987. Calibration of acoustic instruments for fish-density estimation: A practical guide. ICES Cooperative Research Report: 144 pp.

Frankiewicz P, Dąbrowski K, Martyniak A, Zalewski M, 1999. Cannibalism as a regulatory force of pikeperch, Stizostedion lucioperca (L.), population dynamics in the lowland Sulejow Reservoir (Central Poland). Hydrobiologia 408/409:47-55.

Frankiewicz P, Dąbrowski K, Zalewski M, 1996. Mechanism of establishing bimodality in a size distribution of age- 0 pikeperch, Stizostedion lucioperca (L.) in the Sulejów Reservoir. Ann. Zool. Fenn. 33:321-327.

Frankiewicz P, Świerzowski A, 2004. Pattern of spatial fish distribution in the Sulejów reservoir monitored by horizontally beaming echosounder and by gill netting. Hydroacoustics 7:37-43.

Frankiewicz P, Wojtal A, Zalewski M, 2002. Temporal and spatial pattern of zooplanktivory by $0+$ fish and older cyprinids in the zebra mussel dominated lowland reservoir, p. 93-95. In: Extended abstracts 4th International Conference: "Reservoir Limnology and Water Quality”. Ceske Budejovice, Czech Republik.

Frankiewicz P, Zalewski M, Schiemer F, Dąbrowski K, 1997. Vertical distribution of planktivorous pikeperch, Stizostedion lucioperca (L.), in relation to particulate or filter feeding. Fisheries Manag. Ecol. 4 93-101.

Frouzova J, Kubecka J, Balk H, Frouz J, 2005. Target strength of some European fish species and its dependence on fish body parameters. Fish. Res. 75:86-96.

Fulton RS, Paerl HW, 1987. Toxic and inhibitory effects of the blue-green alga Microcystis aeruginosa on herbivorous zooplankton. J. Plankton Res. 9:837-855.

Gągała I, Izydorczyk K, Jurczak T, Mankiewicz-Boczek J, 2012. The key parameters and early warning methods to identify presence of toxigenic blooms dominated by Microcystis aeruginosa in the Jeziorsko Reservoir (Central Poland). Fresen. Environ. Bull. 21:295-303.

Gągała I, Izydorczyk K, Jurczak T, Pawełczyk J, Dziadek J, Wojtal-Frankiewicz A, Jóźwik P, Jaskulska A, MankiewiczBoczek J, 2014. Role of environmental factors and toxic genotypes in the regulation of microcystins-producing cyanobacterial blooms. Microb. Ecol. 67:465-479.

Ger KA, Panosso R, Lurling M, 2011. Consequences of acclimation to Microcystis on the selective feeding behavior of the calanoid copepod Eudiaptomus gracilis. Limnol. Oceanogr. 56:2103-2114.

Ger KA, Hansson L-A, Lurling M, 2014. Understanding cyanobacteria-zooplankton interactions in a more eutrophic world. Freshwater Biol. 59:1783-1798.
Ghadouani A, Pinel-Alloul B, 2002. Phenotypic plasticity in Daphnia pulicaria as an adaptation to high biomass of colonial and filamentous cyanobacteria: experimental evidence. J. Plankton Res. 24:1047-56.

Giovannoni SJ, DeLong EF, Schmidt TM, Pace NR, 1990. Tangential flow filtration and preliminary phylogenetic analysis of marine picoplankton. Appl. Environ. Microbiol. 56:25722575.

Gliwicz ZM, Jachner A, 1992. Diel migrations of juvenile fish: a ghost of predation past or present? Arch. Hydrobiol. 124:385-410.

Godlewska M, Frouzova J, Kubecka J, Wiśniewolski W, Szlakowski J, 2012. Comparison of hydroacoustic estimates with fish census in shallow Malta Reservoir - which TS/L regression to use in horizontal applications? Fish. Res. 123124:90-97.

Guillard J, Perga M-E, Colon M, Angeli N, 2006. Hydroacoustic assessment of young-of-year perch, Perca fluviatilis, population dynamics in an oligotrophic lake (Lake Annecy, France). Fisheries Manag. Ecol. 13:319-327.

Hansson LA, Gustafsson S, Rengefors K, Bomark L, 2007. Cyanobacterial chemical warfare affects zooplankton community composition. Freshwater Biol. 52:1290-1301.

Izydorczyk K, Carpentier C, Mrówczyński J, Wagenvoort A, Jurczak T, Tarczyńska M, 2009. Establishment of an Alert Level Framework for cyanobacteria in drinking water resources by using the Algae Online Analyser for monitoring cyanobacterial chlorophyll a. Water Res. 43:989-996.

Izydorczyk K, Skowron A, Wojtal A, Jurczak T, 2008. The stream inlet to a shallow bay of a drinking water reservoir, a "hot-spot" for Microcystis blooms initiation. Int. Rev. Hydrobiol. 93:257-268.

Izydorczyk K, Tarczyńska M, 2005. The influence of wind on cyanobacterial bloom development in shallow, lowland reservoir in central Poland. Ecohydrol. Hydrobiol. 5:195-203.

Jewel MAS, Affan MA, Khan S, 2003. Fish mortality due to cyanobacterial bloom in an aquaculture pond in Bangladesh. Pak. J. Biol. Sci. 6:1046-1050.

Jurczak T, Tarczyńska M, Izydorczyk K, Mankiewicz J, Zalewski M, Meriluoto J, 2005. Elimination of microcystins by water treatment process - examples from Sulejow Reservoir, Poland. Water Res. 39:2394-2406.

Kopp R, Mares J, Palikova M, Navratil S, Kubicek Z, Zikova A, Hlavkova J, Blaha L, 2009. Biochemical parameters of blood plasma and content of microcystins in tissues of common carp (Cyprinus carpio L.) from a hypertrophic pond with cyanobacterial water bloom. Aquac. Res. 40:1683-1693.

Kotak BG, Semalulu S, Fritz DL, Prepas EE, Hrudey SE, Coppock RW, 1996. Hepatic and renal pathology of intraperitoneally administered microcystin-LR in rainbow trout (Oncorhynchus mykiss). Toxicon 34:517-525.

Kubecka J, 1996. Use of horizontal dual beam sonar for fish surveys in shallow waters, p. 165-178. In: I.G. Cowx (ed.), Stock assessment in inland fisheries. Fishing New Books, Blackwell Science, Oxford.

Lampert W, 1987. Feeding and nutrition in Daphnia. Mem. Ist. Ital. Idrobiol. 45:143-192.

Lazzaro X, 1987. A review of planktivorous fishes: their evolution, feeding behaviours, selectivities, and impacts. Hydrobiologia 146:97-168. 
Li L, Xie P, Chen J, 2005. In vivo studies on toxin accumulation in liver and ultrastructural changes of hepatocytes of the phytoplanktivorous bighead carp i.p.-injected with extracted microcystins. Toxicon. 46:533-545.

Magalhàes FV, Soares RM, Azevedo SMFO, 2001. Microcystin contamination in fish from Jacarepaguá Lagoon (Rio de Janeiro, Brazil): ecological implication and human health risk. Toxicon. 39:1077-1085.

Malbrouck C, Kestemont P, 2006. Effects of microcystins on fish. Environ. Toxicol. Chem. 25:72-86.

Malbrouck C, Trausch G, Devos P, Kestemont P, 2003. Hepatic accumulation and effects of microcytin-LR on juvenile goldfish Carassius auratus L. Comp. Biochem. Physiol. C Pharmacol. Toxicol. 135:39-48.

Mankiewicz-Boczek J, Izydorczyk K, Romanowska-Duda Z, Jurczak T, Stefaniak K, Kokociński M, 2006. Detection and monitoring toxigenicity of cyanobacteria by application of molecular methods. Environ. Toxicol. 21:380-387.

Martin-Creuzburg D, von Elert E, Hoffmann KH, 2008. Nutritional constraints at the cyanobacteria - Daphnia magna interface: The role of sterols. Limnol. Oceanogr. 53:456-468.

Martins JC, Vasconcelos VM, 2009. Microcystin dynamics in aquatic organisms. J. Toxicol. Env. Heal. B 12:65-82.

Mastin BJ, Rodgers JH Jr., Deardorff TL, 2002. Risk evaluation of cyanobacteria dominated algal blooms in a North Louisiana reservoir. J. Aquat. Ecosyst. Stress Recovery 9: 03-114.

Mehner T, Busch S, Helland IP, Emmrich M, Freyhof J, 2010. Temperature related nocturnal vertical segregation of coexisting coregonids. Ecol. Freshw. Fish. 19: 408-419.

Mohamed ZA, Carmichael WW, Hussein AA, 2003. Estimation of microcystins in the freshwater fish Oreochromis niloticus in an Egyptian fish farm containing a Microcystis bloom. Environ. Toxicol. 18:137-141.

Mohamed ZA, Hussein AA, 2006. Depuration of microcystins in tilapia fish exposed to natural populations of toxic cyanobacteria: a laboratory study. Ecotox. Environ. Safe. 63:424-429.

Oberemm A, Becker J, Codd G, Steinberg C, 1999. Effects of cyanobacterial toxins and aqueous crude extracts on the development of fish and amphibians. Environ. Toxicol. 14: 77-88.

Ochumba PBO, 1990. Massive fish kills within the Nyanza Gulf of Lake Victoria, Kenya. Hydrobiologia 208:93-99.

Paerl HW, Otten TG, 2013. Harmful cyanobacterial blooms: Causes, consequences, and controls. Microb. Ecol. 65:995-1010.

Papadimitriou T, Kagalou I, Leonardos I, 2012. Seasonally accumulation of microcystins in the various tissues of an endemic and protected fish species (Rutilus panosi) with different sizes. Clean 40:402-407.

Pflugmacher S, Wiegand C, Oberemm A, Beattie KA, Krause E, Codd GA, Steinberg CEW, 1998. Identification of an enzymatically formed glutathione conjugate of the cyanobacterial hepatotoxin microcystin-LR: the first step of detoxication. Biochim. Biophys. Acta 1425:527-533.

Phillips MJ, Roberts RJ, Stewart JA, 1985. The toxicity of the cyanobacterium Microcystis aeruginosa to rainbow trout, Salmo gairdneri Richardson. J. Fish Dis. 8:339-344.

Porter KG, 1976. Variable gut passage of galatinous green algae ingested by Daphnia. Verh. Int. Verein. Limnol. 19:28402850 .
prEN 14757, 2005. Water quality - Sampling of fish with multimesh gillnets. The European Standard.

Qiu T, Xie P, Guo L, Zhang D, 2009. Plasma biochemical responses of the planktivorous filter-feeding silver carp (Hypophthalmichthys molitrix) and bighead carp (Aristichthys nobilis) to prolonged toxic cyanobacterial blooms in natural waters. Environ. Toxicol. Phar. 27:350-356.

Reichwaldt ES, Song H, Ghadouani A, 2013. Effects of the distribution of a toxic microcystis bloom on the small scale patchiness of zooplankton. PLoS One 8:e66674.

Rodger HD, Turnbull T, Edwards C, Codd GA, 1994. Cyanobacterial (blue-green algal) bloom associated pathology in brown trout (Salmo trutta L.) in Loch Leven, Scotland. J. Fish Dis. 17:177-181.

Rohrlack T, Dittmann E, Henning M, Börner T, Kohl J-G, 1999. Role of microcystins in poisoning and food ingestion inhibition of Daphnia galeata caused by the cyanobacterium $\mathrm{Mi}$ crocystis aeruginosa. Appl. Environ. Microb. 65:737-739.

Roy S, 2008. Spatial Interaction among nontoxic phytoplankton, toxic phytoplankton and zooplankton: Emergence in space and time. J. Biol. Phys. 34:459-474.

Sahin A, Tencalla FG, Dietrich DR, Naegeli H, 1996. Biliary excretion of biochemically active cyanobacteria (blue-green algae) hepatotoxins in fish. Toxicology 106:123-130.

Schwarzenberger A, Zitt A, Kroth P, Mueller S, von Elert E, 2010. Gene expression and activity of digestive proteases in Daphnia: effects of cyanobacterial protease inhibitors. BMC Physiol. 10:6-20.

Sevrin-Reyssac J, Pletikosic M, 1990. Cyanobacteria in fish ponds. Aquaculture 88:1-20.

Sieroslawska A, Rymuszka A, Velisek J, Pawlik-Skowrońska B, Svobodova Z, Skowroński T, 2012. Effects of microcystincontaining cyanobacterial extract on hematological and biochemical parameters of common carp (Cyprinus carpio L.). Fish Physiol. Biochem. 38:1159-1167.

Soares RM, Magalhães VF, Azevedo SMFO, 2004. Accumulation and depuration of microcystins (cyanobacteria hepatotoxins) in Tilapia rendalli (Cichlidae) under laboratory conditions. Aquat. Toxicol. 70:1-10.

Sotton B, Anneville O, Cadel-Six S, Domaizon I, Krys S, Guillard J, 2011. Spatial match between Planktothrix rubescens and whitefish in a mesotrophic pre-alpine lake: Evidence of toxins accumulation. Harmful algae 10:749-758.

Sotton B, Guillard J, Bony S, Devaux A, Domaizon I, Givaudan N, Crespeau F, Huet H, Anneville O, 2012. Impact of toxic cyanobacterial blooms on Eurasian perch (Perca fluviatilis): Experimental study and in situ observations in a peri-alpine lake. PLoS ONE 7:1-12.

Statsoft Inc. 2011. STATISTICA (data analysis software system), ver. 10. Available from: www.statsoft.com

Sun X, Tao M, Qin B, Qi M, Niu Y, Zhang J, Ma Z, Xie P, 2012. Large-scale field evidence on the enhancement of smallsized cladocerans by microcystis blooms in Lake Taihu, China. J. Plankton Res. 34:853-863.

Teegarden GJ, Campbell RG, Anson DT, Ouellett A, Westman BA, Durbin EG, 2008. Copepod feeding response to varying Alexandrium spp. cellular toxicity and cell concentration among natural plankton samples. Harmful Algae 7:33-44.

Tencalla F, Dietrich D, Schlatter C, 1994. Toxicity of Microcystis aeruginosa peptide toxin to yearling rainbow trout $(\mathrm{On}$ - 
corhynchus mykiss). Aquat. Toxicol. 30:215-224.

Trinchet I, Cadel-Six S, Djediat Ch, Marie B, Bernard C, Puiseux-Dao S, Krys S, Edery M, 2013. Toxicity of harmful cyanobacterial blooms to bream and roach. Toxicon 71 : 21-127.

van den Berg C, 1993. Filter-feeding in common bream (Abramis brama), white bream (Blicca bjoerkna) and roach (Rutilus rutilus); structures, functions and ecological significance. PhD Dissertation, Wageningen University, The Netherlands.

Vézie C, Rapala J, Vaitomaa J, Seitsonen J, Sivonen K, 2002. Effects of nitrogen and phosphorus on growth of toxic and nontoxic Microcystis strains and on intracellular microcystin concentrations. Microb. Ecol. 43:443-454.

Wagner I, Izydorczyk K, Kiedrzyńska E, Mankiewicz-Boczek J, Jurczak T, Bednarek A, Wojtal-Frankiewicz A, Frankiewicz P, Ratajski S, Kaczkowski Z, Zalewski M, 2009. Ecohydrological system solution for enhancement of ecosystem services: the Pilica river demonstration project. Ecohydrol. Hydrobiol. 9:13-39.

Walker HW, 2014. Harmful algae blooms in drinking water: removal of cyanobacterial cells and toxins. CRC Press, Boca Raton: 174 pp.

Wang PJ, Chien MS, Wu FJ, Chou HN, Lee SJ, 2005. Inhibition of embryonic development by microcystin-LR in zebrafish Danio rerio. Toxicon 45:303-308.

Wiegand C, Pflugmacher S, 2005. Ecotoxicological effects of selected cyanobacterial secondary metabolites a short review. Toxicol. Appl. Pharm. 203:201-218.
Wojtal-Frankiewicz A, Bernasinska J, Frankiewicz P, Gwoździnski K, Jurczak T, 2014. Response of Daphnia's antioxidant system to spatial heterogeneity in Cyanobacteria concentrations in a lowland reservoir. PLoS ONE 9: e112597.

Wojtalik J, Godlewska M, Frankiewicz P, Zalewski M, 2006. Diurnal and seasonal fish horizontal migrations in the Sulejow Reservoir, Poland. Hydroacoustics 9:217-226.

Woodward G, Warren P, 2007. Body size and predatory interactions in freshwaters: scaling from individuals to communities, p. 98-117. In: G. Hildrew, Raffaelli D.G. and R. EdmondsBrown (eds.), Body size: The structure and function of aquatic ecosystems. Cambridge University Press, Cambridge.

Xie L, Yokoyama A, Nakamura K, Park H, 2007. Accumulation of microcystins in various organs of the freshwater snail Sinotaia histrica and three fishes in a temperate lake, the eutrophic Lake Suwa, Japan. Toxicon 49:646-652.

Xie LQ, Xie P, Guo LG, Li L, Miyabara Y, Park HD, 2005. Organ distribution and bioaccumulation of microcystins in freshwater fish at different trophic levels from the eutrophic Lake Chaohu, China. Environ. Toxicol. 20:293-300.

Xie LQ, Xie P, Ozawa K, Honma T, Yokoyama A, Park HD, 2004. Dynamics of microcystins-LR and -RR in the phytoplanktivorous silver carp in a sub-chronic toxicity experiment. Environ. Pollut. 127:431-439.

Xu H, Paerl HW, Qin B, Zhu G, Hall NS, Wu Y, 2015. Determining critical nutrient thresholds needed to control harmful cyanobacterial blooms in eutrophic Lake Taihu, China. Environ. Sci. Technol. 49:1051-1059. 